\title{
GIRLS AND ECONOMICS: AN UNLIKELY COUPLING?
}

by

\section{ALEX MILLMOW* AND CHERYL BOOKALLIL*}

While total undergraduate enrolments at Australian universities are increasing, enrolments in Economics are falling-a source of alarm for economists. By appealing to females, economics could effectively tap into the largest sector (58\%) of the undergraduate student population. This study suggests that gender is contributing to the falling enrolments. Males need the prospect of money to entice them to study more economics but females require a connection between studying economics and employment opportunities. Providing visible role models may be a practical step to encouraging more females to read economics. More concentration on 'feminising economics' in the undergraduate curricula could help women to believe that they have a contribution to make to the discipline.

Keywords: Non-traditional students, Undergraduate enrolments, Females, Economics majors, Employment opportunities, Business students

JEL Codes: A22, A14

\section{Introduction}

Falling student enrolments in Economics at Australian universities is a source of alarm for economists. A deeper concern, canvassed by this paper, is that Economics is not reaching more than half of the tertiary student market. While females now constitute $58 \%$ of all university enrolments (DEST, 2004a), enrolments of females in undergraduate Economics courses hover around $40 \%$, and fall to $36.5 \%$ for honours and $30.9 \%$ for PhDs (Hopkins, 2004). By appealing to females, Economics could effectively tap into the largest sector of the undergraduate student population. To further that end this study suggests that females need to see a link between studying Economics and employment opportunities before they decide to undertake a major in the field.

In the half century from 1949 to 2000 , enrolments of students in tertiary education increased from 31,753 to 695,485 . Enrolments of females rose from $21.4 \%$ in 1949 to $55.2 \%$ of all university students by 2000 (DEST, 2000). Many of that new generation of

- School of Business, University of Ballarat.

* Freelance economic researcher. 
students accessing higher education have hailed from a 'non-traditional' ${ }^{1}$ background. This trend is fuelled by population growth, by rising living standards, and by the demand for credentials in many employment areas. Access has been improved to higher education by efforts taken under the Federal Government's policies designed to encourage the participation, success, and retention of students from defined equity groups. The establishment of regional universities has also played a major influence by providing opportunities for tertiary study previously only available in the metropolitan areas. Unfortunately Economics has not shared in this growth in student numbers.

During the decade 1989 to 1999, while total Australian undergraduate enrolments increased by $70 \%$, Economics courses saw only a moderate increase of $11 \%$ (DEST, 2000). In the Australian undergraduate student population the percentage share taking a degree in Economics fell from 2.5\% in 1989 to 1.6\% in 1999 (Millmow, 2000).

This paper investigates the reasons why business students in a regional university setting have shunned the study of Economics as a major component of their business course. The study also investigates how gender contributed to the falling enrolments in Economics.

\section{Background and Scope}

The Australian undergraduate student population increased by 70\% from 1989 to 1999 (DEST, 2003). However, enrolments in undergraduate Economics in Australia experienced a much smaller increase of $11 \%$ (Millmow, 2000). Much of this increase in undergraduate enrolments came from females, who by 2004 represented $58 \%$ of all students (DEST, 2004a).

Between 1983 and 2000 females in 'Business, Admin, Economics' increased from $29.5 \%$ to $49 \%$ of total enrolments (DEST, 2003). However, by aggregating business, Administration and Economics into one field the problem of falling enrolments in Economics degrees and Economics majors was disguised. State enrolment figures for Economics courses during 2000 and 2001 show a correlation between female enrolments in the subject and overall enrolments in Economics (DEST, 2002, cited in Millmow, 2002, p. 25). South Australia and the ACT dramatically increased the percentage of females enrolled in Economics. Consequently, given the weight of numbers, these states increased their overall enrolments in Economics. In Victoria, where the enrolment of females was falling, overall Economics enrolment also fell. In the states where female enrolments were relatively stable, overall enrolments figures were also relatively stable.

Identifying and attempting to redress falling enrolments in Economics is much more important an issue than just ensuring that academic economists retain their jobs. If $75 \%$ of students choose to attend university for employment-related reasons (Smith et al., 2000), it may be an example of uninformed student choice that goes to the heart of ensuring equity and 'upward mobility' for those who seek it. Equal opportunity and fairness form part of a continuum from secondary school to university to the primary labour market. The rise in 'credentialism' means that the demand for university places is

\footnotetext{
Non-traditional student cohorts include those with low income, rural and isolated backgrounds, no previous history of university education in the family, disability, female gender, or indigenous (i.e., groups that have been traditionally under-represented in university populations).
} 
likely to continue. The fact that students are not enrolling in Economics degrees, but choosing majors they perceive to be more vocationally oriented, could indicate another dimension to the equity problem. According to Richardson (1995, p. 52) "Equality of opportunity has no obvious link with equality of outcomes". Research conducted by James (1999, p. 107) concerning the decision-making of non-traditional university students suggests that "prospective students' choices are far from equal, being closely associated with their family and community circumstances". To underscore this point Table 1 shows that students at a large regional university who elected to study Economics secured better labour market outcomes, or were more likely to engage in postgraduate study, than students drawn from other business disciplines. This corroborates the recent findings of Lewis, Daly and Fleming (2004) about Economics graduates achieving higher salaries than graduates in law and business

TABLE 1

EMPLOYMENT, FURTHER STUDY, STARTING SALARIES FOR BUSINESS GRADUATES

\begin{tabular}{lccc}
\hline & $\begin{array}{c}\text { Full-time } \\
\text { employment }\end{array}$ & $\begin{array}{c}\text { Further full- } \\
\text { time study }\end{array}$ & $\begin{array}{c}\text { Median starting salary } \\
(\text { A } \$)\end{array}$ \\
\hline $1999 \quad$ & & \\
Business Studies & 80.2 & 14.3 & 30,000 \\
Accounting & 88.8 & 12.7 & 29,000 \\
Economics & 83.1 & 27.2 & 30,400 \\
2000 & & & 30,000 \\
Business Studies & 83.9 & 15.6 & 30,000 \\
Accounting & 91.9 & 11.9 & 33,200 \\
Economics & 86.1 & 29.8 & 32,000 \\
2001 & & & 33,532 \\
Business Studies & 82.7 & 14.6 & 35,000 \\
Accounting & 93.4 & 10.5 & \\
Economics & 86.1 & 28.2 & 33,000 \\
2002 & & & 34,000 \\
Business Studies & 78.9 & 17.5 & 36,000 \\
Accounting & 90.7 & 10.6 & 35,000 \\
Economics & 86.7 & 29.0 & 35,000 \\
2003 & & & 37,400 \\
Business Studies & 76.9 & 16.8 & \\
Accounting & 87.5 & 9.6 & 35,000 \\
Economics & 81.8 & 33.4 & 35,000 \\
2004 & & & 38,700 \\
Business Studies & 80.1 & 16.4 & \\
Accounting & 87.1 & 9.4 & \\
Economics & 85.1 & & \\
\hline
\end{tabular}

Source: Grad files 1999, 2000, 2001, 2002, 2003, 2004.

The increasing enrolment in Business degrees by non-traditional students does not therefore generate the same labour market outcomes as those who choose the traditional Economics degrees and Economics majors. This possible problem (based upon intuition) has some support from the findings of this investigation, but needs to be 
explored further. Early investigation on the basis of the data would seem to suggest that traditional students were more likely than new generation students to select Economics as their major.

FIGURE 1

BUSINESS DEGREE CHOICES AND THE EXPECTED OUTCOMES

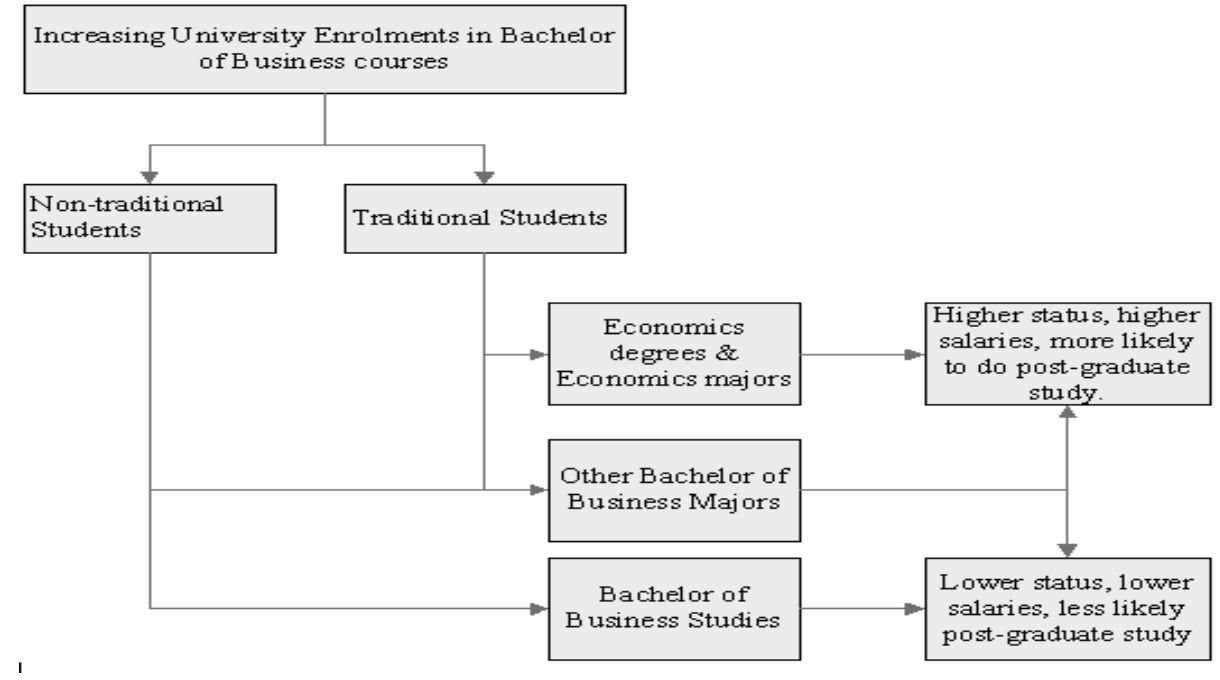

\section{Methodology}

Following Alauddin and Butler (2004), our investigation covered three areas: student profile data; surveying the opinions of Business academics; and surveying Business students. However, unlike Alauddin and Butler's study, our analysis relates to how Economics fares at Business schools where students can only do a major or doublemajor in Economics. Our study has resonance in that many economists find that the service teaching of Economics to business students is their staple. That foothold within a Business school is sometimes under threat as students, and perhaps some of their instructors, talk about reducing the Economics component.

Three variables identified as having an impact upon the Business student's decisions to eschew Economics were: first, their understanding of Economics and what economists do; second, the perceived rigour and relevance of the subject; and, third, the perceived gender domination of the discipline. The research question was further narrowed to determine how much of the decline in Economics enrolments could be attributed to exogenous causes and how much it might be attributed to the discipline itself and those who teach it.

Data were collected from three different sources. Student profile data from the university were analysed to quantify the choice of Business speciality by gender. Thirtytwo academics from other Business disciplines at the same university were surveyed to gather information about their views on Economics. Responses to student questionnaires provided data on demographics, their prior exposure to Economics and 
attitudes to the gender dominance of the discipline. Ninety-seven student questionnaire responses involving both modes of study were analysed to test how these three factors affected students' study choices.

\section{Doing Business without Economics?}

It is now a commonplace that while some Business courses are increasing in popularity, some, notably Economics, are waning. The profusion of business degree specialisations in itself reflects the flowering of vocations and professions in a sophisticated, diverse economy.

TABLE 2

STUDENT ENROLMENT PROFILE 1997 TO 2002-BACHELOR OF BUSINESS, ALL SPECIALITIES.

\begin{tabular}{|c|c|c|c|c|c|c|c|c|}
\hline Course & 1997 & 1998 & 1999 & 2000 & 2001 & 2002 & Change & $\%$ Change \\
\hline$\overline{\text { BBus (Acc) }}$ & 1646 & 1627 & 1716 & 1949 & 2037 & 2016 & +370 & +22.50 \\
\hline BBus (Bank) & 72 & 80 & 112 & 123 & 90 & 101 & +29 & +40.27 \\
\hline BBus (ElectCom) & & & 16 & 46 & 81 & 98 & +82 & +512.00 \\
\hline BBus (Fin) & 158 & 199 & 239 & 382 & 372 & 363 & +205 & +129.00 \\
\hline BBus (HRM) & 323 & 394 & 367 & 390 & 391 & 398 & +75 & +23.00 \\
\hline BBus (Mkt) & 522 & 590 & 681 & 943 & 887 & 770 & +248 & +47.50 \\
\hline BBus Studies & & 1 & 72 & 290 & 587 & 733 & +732 & +732.00 \\
\hline BBus (BusMgt) & 518 & 614 & 765 & 1105 & 1043 & 925 & +407 & +78.50 \\
\hline $\begin{array}{l}\text { Bbus } \\
\text { (Acc/Comp/Econ) }\end{array}$ & 11 & 9 & 3 & 1 & 1 & 1 & -10 & -90.00 \\
\hline BBus (Admin) & 33 & 11 & 3 & 1 & 1 & 1 & -32 & -97.00 \\
\hline BBus (Bank\&Fin) & 14 & 8 & 5 & 2 & 3 & 2 & -12 & -85.71 \\
\hline BBus (Econ) & 95 & 70 & 48 & 43 & 41 & 27 & -68 & -71.50 \\
\hline BBus (IndRel) & 87 & 66 & 51 & 44 & 35 & 26 & -61 & -70.11 \\
\hline $\begin{array}{l}\text { Bbus } \\
\text { (Public Admin) }\end{array}$ & 67 & 64 & 56 & 50 & 43 & 40 & -27 & -40.29 \\
\hline BBus (TourismMgt) & 179 & 186 & 160 & 132 & 104 & 90 & -89 & -49.72 \\
\hline $\begin{array}{l}\text { BBus (Bank\&Fin) } \\
\text { (Cwlth/Ind) }\end{array}$ & 5 & 2 & 1 & & & & $\mathrm{n} / \mathrm{a}$ & $\mathrm{n} / \mathrm{a}$ \\
\hline BBus (Insurance) & & & & & & 23 & $\mathrm{n} / \mathrm{a}$ & $\mathrm{n} / \mathrm{a}$ \\
\hline BBus (LocalGov) & 38 & 24 & 7 & 3 & & & $\mathrm{n} / \mathrm{a}$ & $\mathrm{n} / \mathrm{a}$ \\
\hline BBus (Mgt) & 1 & 1 & & & & & $\mathrm{n} / \mathrm{a}$ & $\mathrm{n} / \mathrm{a}$ \\
\hline BBus (Various) & 14 & 5 & 2 & 16 & & & $\mathrm{n} / \mathrm{a}$ & $\mathrm{n} / \mathrm{a}$ \\
\hline BHotel Mgt & & & & & & 11 & $\mathrm{n} / \mathrm{a}$ & $\mathrm{n} / \mathrm{a}$ \\
\hline BBus(Acc) (Hons) & 1 & & 1 & 1 & 1 & 2 & & \\
\hline BBus (Hons) & 5 & 3 & 7 & 2 & 3 & 9 & & \\
\hline TOTAL & 3789 & 3954 & 4311 & 5523 & 5720 & 5636 & +1847 & +48.74 \\
\hline
\end{tabular}


The trends in Business degree enrolments over a five-year period at an Australian regional university are shown in Table 2. Amongst the profusion of business specialisations it is noted how the Bachelor of Business major in Economics fell alarmingly while other courses, though not all, grew. There would be some pick-up of Economics subjects with the strength of the degree specialisation in finance. Another interesting point to note is that the Bachelor of Business Studies with its phenomenal growth rate contained no Economics component within its regimen. More and more Business graduates, barely equipped with some command of Economics are entering the world of commerce.

\subsection{Female Enrolments}

A correlation can be seen between enrolments of females in Business courses and total enrolments (Table 3). Those Business specialties that had improved their percentage enrolment of women over the five years from 1998 to 2002 also improved overall course enrolments. Those Business specialties that may be considered closer to the traditional employment roles of females are the ones with a higher level of female enrolments. A good example of this is Human Resource Management, where the percentage of female enrolments rose from an already dominant $63 \%$ in 1998 to $75 \%$ of all enrolments in 2002.

TABLE 3

GENDER ENROLMENT FOR SELECTED BACHELOR OF BUSINESS SPECIALISATIONS 1998 TO 2002

\begin{tabular}{|c|c|c|c|c|c|c|c|c|c|c|c|c|c|c|c|}
\hline & & & 1998 & & & 1999 & & & 2000 & & & 2001 & & & 2002 \\
\hline 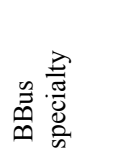 & 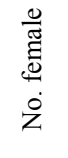 & 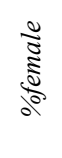 & $\bar{\psi}$ & 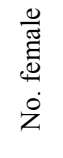 & $\frac{\frac{d}{\tilde{\Xi}}}{\frac{5}{5}}$ & $\bar{\psi}$ & $\begin{array}{l}\frac{0}{\tilde{Z}} \\
\stackrel{0}{0} \\
\dot{0} \\
\dot{Z}\end{array}$ & $\frac{\stackrel{0}{\Xi}}{\frac{0}{0}}$ & $\bar{\psi}$ & 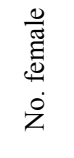 & 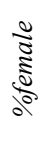 & 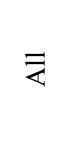 & $\begin{array}{l}\frac{0}{\pi} \\
\stackrel{\Xi}{0} \\
\dot{0} \\
\dot{z}\end{array}$ & 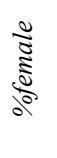 & $\bar{\psi}$ \\
\hline$\overline{(\mathrm{Acc})}$ & 842 & 52 & 1627 & 948 & 55 & 1716 & 1113 & 57 & 1949 & 1204 & 59 & 2037 & 1232 & 61 & 2016 \\
\hline (Bank) & 27 & 34 & 80 & 47 & 42 & 112 & 62 & 50 & 123 & 47 & 52 & 90 & 54 & 53 & 101 \\
\hline (Econ) & 23 & 33 & 70 & 18 & 37 & 48 & 19 & 44 & 43 & 17 & 42 & 41 & 10 & 37 & 27 \\
\hline (ECom) & & & & 6 & 37 & 16 & 13 & 28 & 46 & 36 & 44 & 81 & 41 & 42 & 98 \\
\hline (Fin) & 83 & 42 & 199 & 107 & 45 & 239 & 181 & 47 & 382 & 180 & 48 & 372 & 180 & 49 & 363 \\
\hline (HRM) & 247 & 63 & 394 & 241 & 66 & 367 & 279 & 71 & 390 & 287 & 73 & 391 & 301 & 75 & 398 \\
\hline (IndRel) & 28 & 42 & 66 & 20 & 39 & 51 & 17 & 38 & 44 & 16 & 46 & 35 & 11 & 42 & 26 \\
\hline (Mkt) & 293 & 50 & 590 & 359 & 53 & 681 & 524 & 55 & 943 & 499 & 56 & 887 & 418 & 54 & 770 \\
\hline $\begin{array}{l}\text { (Public } \\
\text { Admin) }\end{array}$ & 31 & 48 & 64 & 27 & 48 & 56 & 29 & 58 & 50 & 26 & 60 & 43 & 23 & 58 & 40 \\
\hline $\begin{array}{l}\text { (Tourism } \\
\text { Mgt) }\end{array}$ & 128 & 69 & 186 & 110 & 69 & 160 & 89 & 67 & 132 & 73 & 70 & 104 & 60 & 67 & 90 \\
\hline $\begin{array}{l}\text { BBus } \\
\text { Studies }\end{array}$ & 1 & 100 & 1 & 39 & 54 & 72 & 157 & 54 & 290 & 329 & 56 & 587 & 410 & 56 & 733 \\
\hline (BusMgt) & 278 & 45 & 614 & 390 & 51 & 765 & 590 & 53 & 1105 & 552 & 53 & 1043 & 505 & 55 & 925 \\
\hline
\end{tabular}




\subsection{How Business Academics See Economics}

Half of the sixty-four non-Economics staff within the Commerce Faculty at this university provided feedback to the staff survey. At one extreme some respondents said they appreciated Economics while at the other respondents despised it. The remainder was split between those who agreed that Economics added quality for the Business graduate and those who felt that the current direction of teaching Economics may not be appropriate. The fact that less than $50 \%$ of non-Economics academic staff who responded to the survey believed strongly in the relevance of Economics study for the Business students is extremely important. Almost $40 \%$ qualified a positive response with less positive comments concerning the current teaching of Economics, or the relevance of Economics to their own Business speciality. These findings point to a need for economists to ensure that all Business School colleagues have knowledge of Economics and how it relates to, and interacts with the other disciplines.

\subsection{Student Career Choices}

A quick result from this survey was that teachers and career advisers do not, in fact, have the greatest influence on students' choice of tertiary study. Half of the students undertaking a Business degree chose their course on the basis of family advice, even where the parents had not attended university themselves. Only four of the ninety-seven students who responded to the survey were Economics majors. All were male. Interestingly all four had family members who had been university educated. This profile contrasts with the thirty-six accounting majors for whom sixteen (44\%) came from families where there was no prior history of university education. The profile of a traditional student could be considered to be white, male, and from a high socioeconomic status background. High socio-economic status refers not only to family income, but also to the parents' professional employment and educational level.

\subsection{How Business Students Rated Economics}

Students were asked to rank their enjoyment of Economics on a five-point Likert scale. The ninety-seven responses to this question showed that students were not enjoying their first exposure to Economics. Almost half of them ranked their enjoyment of Economics as moderate while only a quarter ranked their enjoyment as high or very high. In sum, approximately $75 \%$ of all students ranked their enjoyment of Economics study as moderate, low, or very low.

After ranking their level of enjoyment the students were asked to comment on "What might have improved your enjoyment of Economics?" Almost half of all students provided some comment on this question (Figure 2). Fifty-one per cent of students expressed dissatisfaction with the teaching style. This should send a clear message to the staff involved in teaching Economics since teaching style is the element over which they have the most control. Macroeconomics was the subject found most interesting by $44 \%$ of students. This compares with only $20 \%$ for Microeconomics.

Students were also asked to rank their understanding of Economics on a five-point Likert scale. More than half of the males and half of the females ranked their understanding of Economics as moderate. When asked to comment on what would have improved their comprehension of the subject a third of the students accepted that their 
own efforts could affect their grades. More study effort by student, lack of interest/understanding in subject and teaching style accounted for $83 \%$ of what the students felt would have improved their achievement in Economics. The lack of interest/understanding and teaching style are all elements that Economics teaching staff can alter to some extent. In turn, this may encourage the students to apply greater effort, since it is easier to spend time on a subject that the student finds interesting.

\section{FIGURE 2 \\ FACTORS THAT REDUCED STUDENTS' ENJOYMENT OF ECONOMICS STUDY}

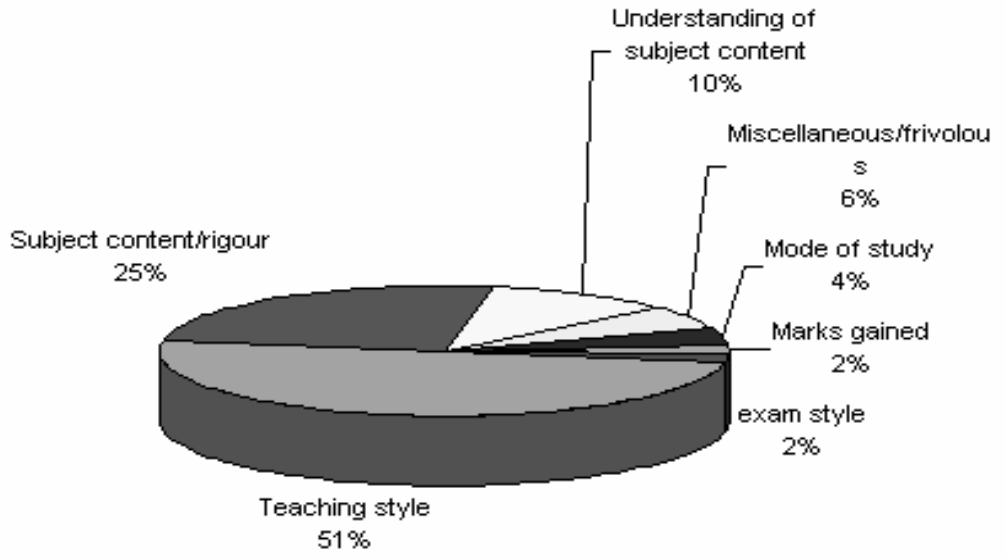

Business students were also asked to rank the importance of studying Economics: $80 \%$ agreed or strongly agreed that it was important to study the subject. However, $71 \%$ of the respondents could not articulate any reasons for studying Economics. There is a need to teach the relevance and importance of Economics to Business students early in their first semester. Economists cannot assume that the students instinctively know why Economics will be good for their education as Business students.

\subsection{Economics and Employment Possibilities}

Students were also asked to consider whether studying Economics might improve their chances of gaining employment. The answers show a difference in the rankings given by gender: $67 \%$ of males agreed or strongly agreed with the proposition that knowledge of Economics was beneficial to Business students whereas only $46 \%$ of females agreed or strongly agreed. Conversely a larger percentage of females (42\%) than males (19\%) were unsure whether Economics assisted their employment chances. A huge $76 \%$ of all students could not articulate any reasons why Economics might assist their employment prospects.

When asked if the study of Microeconomics and Macroeconomics encouraged students into undertaking more Economics subjects a large proportion disagreed and just as many were unsure (Table 4). More striking was the fact that $35 \%$ of males and $57 \%$ of the females foreswore further study of Economics., which shows that females 
had, generally speaking, a less positive experience in their introduction to Economics than males.

\subsection{Gender Issues in Economic Instruction}

A difference in opinion between males and females was also obvious when analysing the question of whether they thought it was a 'good thing' that male instructors dominated the teaching of Economics. Males appear to be more comfortable with the gender dominance of Economics teaching than females, with $30 \%$ of the males indicating that male domination of Economics teaching was acceptable while only $9 \%$ of females agreed (Table 5).

TABLE 4

STUDYING MICROECONOMICS AND MACROECONOMICS MADE ME WISH TO UNDERTAKE MORE ECONOMICS SUBJECTS

\begin{tabular}{lrrrrr}
\hline & Males & $\%$ & Females & $\%$ & Total \\
\hline Agree Strongly & 5 & 12 & 4 & 7 & 9 \\
Agree & 7 & 16 & 6 & 11 & 13 \\
Unsure & 13 & 30 & 12 & 22 & 25 \\
Disagree & 10 & 23 & 26 & 48 & 36 \\
Disagree Strongly & 5 & 12 & 5 & 9 & 10 \\
Not stated & 3 & 7 & 1 & 2 & 4 \\
Total & 43 & & 54 & & 97 \\
\hline
\end{tabular}

Although this question was presented in a binary structure (yes/no), more than $25 \%$ of respondents indicated no preference either way and some did not state a preference. The data for the two genders, where they could choose one of four possible answers, replicates a multinomial experiment that can be subjected to a chi-squared test. Since the frequencies of the 'not stated' response are not within the 'rule of five' required for the test statistic to be adequately approximated by the chi-squared distribution (Selvanathan et al., 2000, 589) this category was combined with the 'no preference' responses. A chi-squared test shows a p-value of 0.0274 , indicating that there is a significant difference in the responses between males and females at the $5 \%$ level.

TABLE 5

DO YOU THINK IT GOOD THAT ECONOMICS TEACHING IS DOMINATED BY MALES?

\begin{tabular}{lccccc}
\hline & Males & $\%$ & Females & $\%$ & Total \\
\hline No preference & 10 & $23 \%$ & 18 & $33 \%$ & 28 \\
Yes & 13 & $30 \%$ & 5 & $9 \%$ & 18 \\
No & 17 & $39 \%$ & 25 & $46 \%$ & 14 \\
Not stated & 3 & $7 \%$ & 6 & $11 \%$ & 9 \\
Total & 43 & & 54 & & 97 \\
\hline Test Statistic chi-Squared $=7.1947 ;$ p-value $=0.0274$ &
\end{tabular}


Because the question could be perceived as a 'leading question' it was deliberately structured in the positive. It obviously hit a nerve and generated the most student comment of all the survey questions, with $64 \%$ providing written comment. Female comments were all fairly benign. However, almost a third of the male comments were quite strongly male-biased. Only five of the females and four of the males $(10 \%$ of total) indicated confidence in women's capability with the discipline by commenting directly on the need for a mix of gender in Economics teaching. When asked about the related issue of most Economics textbooks being written by men, more students $(33 \%)$ had no preference. Again, more females (37\%) than males (28\%) had no preference. In sum, males appear to be more comfortable with the gender dominance of both Economics teaching and Economics textbooks than females. However, females are more likely than males to express no particular preference or not answer the question.

\subsection{What Factors Might Encourage More Majors in Economics?}

Students were asked to list factors that might encourage them to consider undertaking a major in Economics. After being split on gender the responses were grouped in order to gain general insights. Almost $50 \%$ of the females' responses suggested that a better understanding, changes to the teaching methods and content, and/or employment opportunities might encourage them to do a major in Economics. Twenty-nine per cent of females suggested that nothing could encourage them to study a major in Economics (Figure 3). This compares to only $15 \%$ of males for whom nothing could entice them toward that option (Figure 4).

FIGURE 3

FACTORS THAT COULD ENCOURAGE FEMALES TO DO ECONOMICS MAJOR

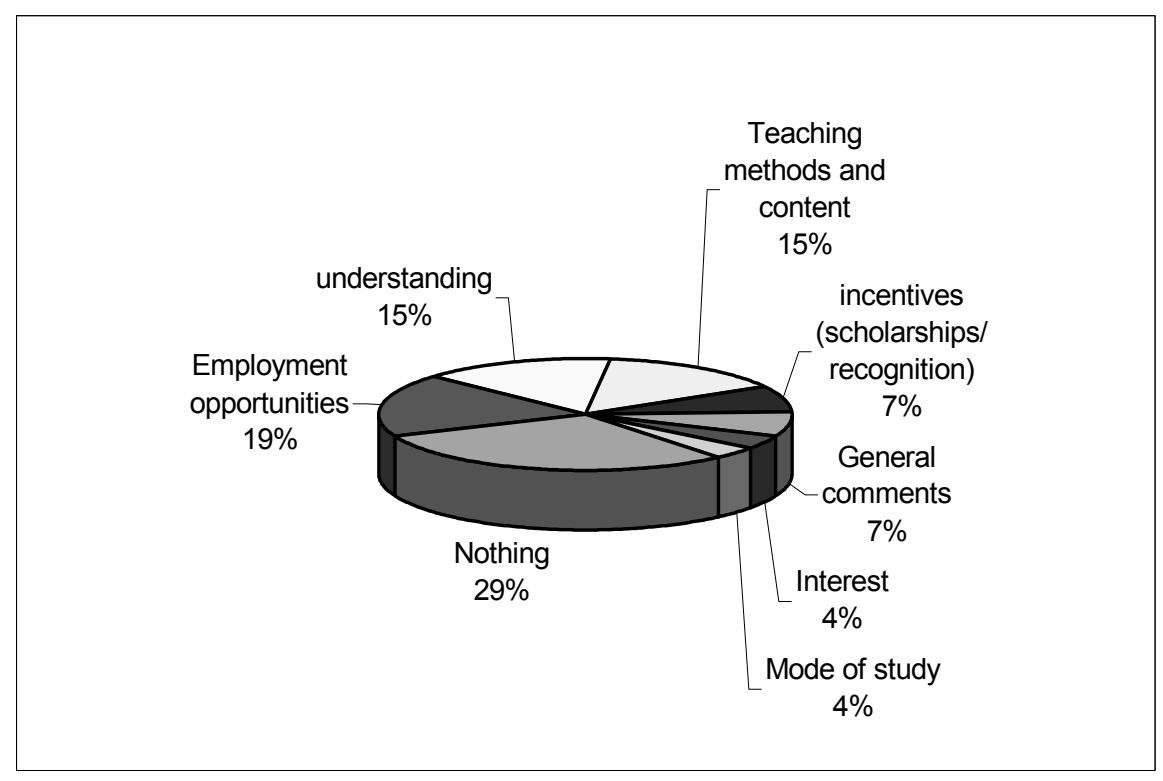


FIGURE 4

FACTORS THAT COULD ENCOURAGE MALES TO DO ECONOMICS MAJOR

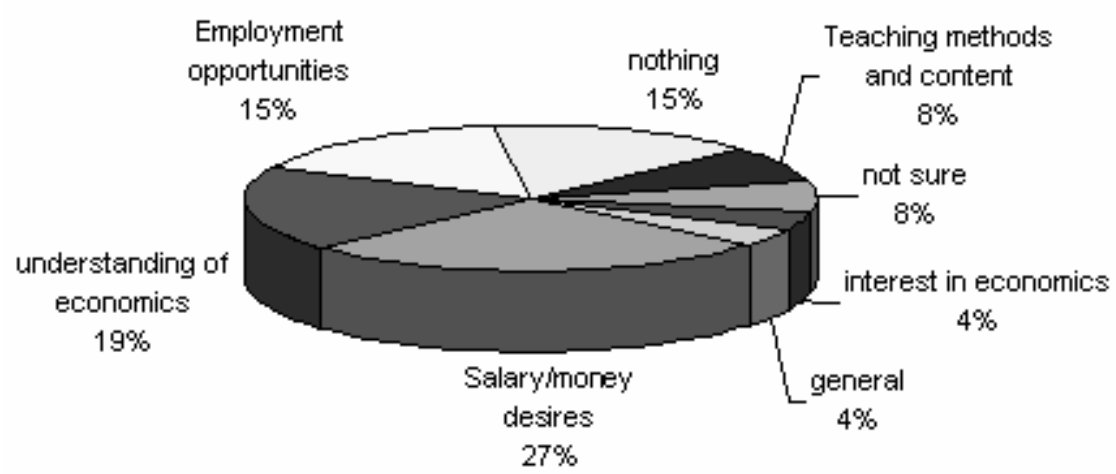

The issue of whether the attitudes of other academic staff actually encouraged students to undertake more Economics was met by a mostly negative response, with $64 \%$ saying they had not been encouraged. Less than a quarter of students were considering further Economics subjects. When asked if they planned to study any more Economics subjects, more males (25\%) than females (22\%) answered in the affirmative. More females (65\%) than males (56\%) answered 'no'. Sixty per cent of all Business students surveyed indicated that they did not plan to study any more Economics.

\section{Summary of Results and Implications}

Statistical data shows that the largest proportion of students enrolled in Australian universities are female. A correlation exists between the direction of female enrolments and the direction of overall enrolments. If females and other 'non-traditional' students decide against studying Economics we can expect the proportion of all students undertaking an Economics degree to decline.

The gender enrolment profile of Bachelor of Business courses at this regional university demonstrates this correlation between the direction of female enrolments and the direction of overall enrolments. Economics, which had witnessed the greatest decline in its enrolments, was found to be the only Bachelor of Business course that decreased both its numbers of women and also suffered a decline in the proportion of females to total course enrolments.

Business school academics who teach subjects other than Economics, were polarised in their opinions of Economics and as to its relevance to business students. Some commended Eonomics for the skills and attributes it can instil, while others dismissed it completely as over-rated and no longer relevant for the Business graduate. Some examples of 'echoing' these sentiments could be found in the responses from students in their survey forms. This is important because these people will have some influence on the subject choices that Business students may make. Academic economists may have a role in this respect to encourage understanding of their discipline among their peers and 
highlight the interrelations between Economics and other business disciplines. If firstyear Economics subjects can be used as marketing tools, as Allauddin (2002) suggests, then all staff need to be aware of, and appreciate, the benefits of Economics for the Business graduate.

An interesting equity issue may also be emerging among Business graduates. Those who study Economics enjoy higher outcomes in terms of salaries and career advancement than other Business graduates. Family advice appears to carry more weight in the decision-making process, even when the family has no experience of university study and may not understand the different employment outcomes for different degree choices.

More than three-quarters of all students surveyed were not enjoying their Economics units and attributed this to teaching styles, subject content, and the degree of rigour required. Students appear to enjoy Macroeconomics better than Microeconomics. If first-year subjects can be used as a marketing tool then maybe introducing Business students to Macroeconomics as their first Economics subject could have positive affects upon student experience and, as a consequence, a positive affect upon enrolments in Economics majors. There was also some evidence that males enjoy Microeconomics more than females do. Males also appear to have a more positive experience of Economics in general, and appear more confident in their capabilities with the discipline of the subject than females.

Significantly, $61 \%$ of respondents in the survey commenced their Business course without any previous exposure to Economics. Since Economics is declining as an elective at secondary school and also at TAFE (Millmow, 2003) this is not surprising. Lack of preparedness for Economics study at university level may lie behind the figures, showing that many students neither enjoy the subject nor achieve good grades in Economics. Perhaps the lesson here is for universities to offer a bridging course in the fundamentals of Economics so that Business students will be better equipped to deal with the rigours of first-year university Economics.

Neither males nor females had any strong disagreement with the proposition that doing Economics improved their employment prospects. However, few could articulate why or how. Gender appears to be a factor in here, since $42 \%$ of females were unsure how Economics might help them. In isolating the factors that would be likely to encourage students to consider undergoing a major in Economics, employment opportunities struck a strong note with females.

Males appear to be much more comfortable with the gender dominance of Economics teaching and textbook authorship than females. Overall, females, whose answers were benign and accepting of the status quo, do not appear to have strong feelings against the 'male domination'. However one third of female students said that nothing could attract them to undertake further Economics subjects. This was twice the rate of males. The strongest encouragement factor for males to do a major in Economics was salary. In contrast, females nominated employment opportunities as the key factor likely to encourage them to complete a major in Economics. This indicates a link between equity in higher education and equal employment opportunity in the workforce. Females may be resisting Economics because the male dominance of the profession generates a perception that employment opportunities for women are lacking. Of course, if females do not study Economics it perpetuates male dominance within the profession. 
Overall Business students do believe that Economics is an important discipline for them or that it could assist their employment chances. However, few could articulate why. This indicates an aspect of Economics that can usefully be taught early in the first Economics subject that students encounter. It is therefore important that first-year Economics instructors include information about what an economist is and does and the lines of employment in which they may engage.

\section{Conclusion}

Part of that concern about the relatively static enrolments in Economics within Australian universities focuses upon how it is not tapping into the largest proportion of the undergraduate student population. Some might believe that this does not matter. But quite apart from keeping the discipline nourished with new blood it matters because Economics graduates are likely to have better employment and career outcomes than graduates from other business courses. This indicates an equity issue in that uninformed student choices may result in lesser outcomes for those 'non-traditional' Business students who do not consider undertaking a major in Economics. The study has also suggested a link between equal opportunity in the workforce and equity in higher education, in that females would probably study more Economics if they felt confident of improved employment prospects thereby.

Lack of understanding of Economics and what economists actually do has some bearing upon students' decision in choosing their business major. However the initial course choices of students are beyond the reach of academic staff and not open to change. That said, those who do teach the core subjects of first-year Macroeconomics and Microeconomics can make some amends, particularly when Business students come to classes without any prior exposure to Economics. Academic economists need to show clearly the relevance of Economics to the other Business disciplines.

About three-quarters of first-year Business students neither enjoyed nor did well in their Economics component. Is it possible that there is unnecessary rigour in the classroom? Could the teaching style that affects students' enjoyment of Economics be affected in turn by the domination of the discipline by male academics? More investigation of these ideas is recommended.

Males need the prospect of money to entice them to study more Economics. Females, it seems, need employment opportunities. Demonstrating where economists are employed could spark student interest, particularly amongst women. The rigour and perceived relevance of the subject content is partly a matter of course design. Moreover, providing role models, by actively encouraging females into the teaching of Economics at university level, may be a practical step to encouraging more females to read Economics. More concentration on 'feminising Economics' in the undergraduate programmes and highlighting female role models, and women who have made a contribution to Economics, would help women to believe that they may have a contribution to make to the discipline.

\section{REFERENCES}

Alauddin, M. (2002) “Causes and Implications of Declining Economics Major: A Focus on Australia", Paper presented at the $9^{\text {th }}$ Annual Teaching Economics Conference, University of Queensland, 3-5 July 2002. 
Alauddin, M. and Butler J. (2004) "Teaching Economics in a Changing University Environment”, International Journal of Social Economics, 31, pp. 706-720.

Department of Education, Employment and Training (DEET) (1990), A Fair Chance for All: Higher Education that's within Everyone's Reach (Canberra: AGPS).

Department of Education Science and Training (DEST) (2000) "Higher Education Students Time Series Tables" http://www.dest.gov.au/highered/statistics/students/03/student tables/tables/.

Department of Education Science and Training (DEST) (2003) "Higher Education Students Time Series Tables" http://www.dest.gov.au/highered/statistics/students/03/student tables/tables/.

Department of Education Science and Training (DEST) (2004a) "Higher Education Students Time Series Tables" http://www.dest.gov.au/highered/statistics/students/03/student tables/tables/.

Department of Education Science and Training (DEST) (2004b) National State Equity Data (Canberra: Equity Unit, Higher Education Group, Department of Education, Science and Training,).

Gradlink (2005) The Grad Files 1999, 2000, 2001, 2002, 2003, 2004, http://www.gradlink.edu.au/content/view/full/24, viewed April, 2005.

Hopkins, S. (2004) "Women in Economics Departments in Australian universities: Is There Still a Gender Imbalance?", Economic Papers, 23, pp. 201-210.

James, R. (1999) "Helping Prospective Students Make Informed Choices: Equity and Quality in Student Decision-making", Paper presented at the Education '99 Conference, 23-24 March, Sydney.

Lewis, P., A. Daly and D. Fleming (2004) "Why Study Economics? The Private Rate of Return to an Economics Degree", Economic Papers, 23, pp. 234-243.

Lewis, P. and K. Norris (1997) "Recent Changes in Economics Enrolments", Economics Papers, 16, pp. 1-13.

Millmow, A. (2000) “The State We're In: University Economics 1989/1999”, Economic Papers, 19, pp. 43-51.

Millmow, A. (2003) "The Teaching of Economics in Schools: A Problem in the Making', Economic Analysis and Policy, 33, pp. 126-135.

Richardson, S. (1995) "Education and Social Justice", Efficiency and Equity in Education Policy Conference Papers, Australian National University.

Selvanathan A, S. Selvanathan, G. Keller and B. Warrack (2000) Australian Business Statistics (Melbourne: Nelson Australia).

Smith C, G. Isaacs, A. Holzl, D. Herbert and K. Roulston (2000) 'The First Cohort at a New Campus: Who are They? What do They Bring? Where Are They Going? Why did They Come?", Australian Society for Educational Technology and the Higher Education Research and Development Society of Australasia Conference, University of Southern Queensland, Toowoomba, July. 